\title{
LOSS OF P16 IN ESOPHAGEAL ADENOCARCINOMA DETECTED BY FLUORESCENCE IN SITU HYBRIDIZATION AND IMMUNOHISTOCHEMISTRY
}

\author{
A. Kotzev' ${ }^{1}$ M. Kamenova ${ }^{2}$ \\ ${ }^{1}$ Department of Propedeutics of Internal Diseases, Medical University - Sofia, Bulgaria \\ 2Department of Clinical Pathology, University Hospital "Pirogov" - Sofia, Bulgaria
}

\begin{abstract}
Molecular biology of esophageal adenocarcinoma (EAC) is not fully elucidated. The aim of this study was to assess the expression of cycle regulator and tumor suppressor p16 in esophageal adenocarcinoma. The expression of $p 16$ at protein and gene level was investigated using immunohistochemistry and fluorescence in situ hybridization in thirteen EAC specimens obtained by endoscopic biopsies and surgical resections. The mean age of enrolled patients was 62 years and a male predominance was observed. Loss of $p 16$ protein expression was detected in $77 \%$ of the cases and loss of p16 gene was found in $69 \%$ of cases as hemizygous deletion was the most common. Significant correlation was found between the absence of $p 16$ protein expression and $p 16$ allelic loss. Cell cycle disturbances seem to play role in the EAC carcinogenesis and probably p16 gene deletions are connected with the loss of $p 16$ protein expression.
\end{abstract}

Key words: esophageal adenocarcinoma, p16, immunohistochemistry, fluorescence in situ hybridization

Corresponding author: Andrey Iskrenov Kotzev, MD, PhD, Department of Propedeutics of Internal Diseases, Medical University - Sofia, Bg-1431 Sofia, e-mail: dr_andrey_kotzev@abv.bg

\section{INTRODUCTION}

$\mathrm{E}$ sophageal adenocarcinoma (EAC) generally has a very poor prognosis [1]. The incidence of EAC has increased substantially during the last four decades in Western countries and probably will continue to rise [2]. Carcinogenesis of EAC is a complex, multistep and multifactorial process in which a lot of genetic abnormalities are discovered. Nevertheless, molecular alterations in EAC are not completely clarified. Inactivation of tumor suppressors responsible for the maintenance of normal cell cycle often occurs in the carcinogenesis of EAC [3]. One of the key molecular players in the cell cycle con- trol is $p 16$. Tumor suppressor $p 16$ is a cyclin-dependent kinases (cdk) inhibitor that blocks the activity of cyclin-D-cdk4/6 complex, and thus inhibits the phosphorylation of $p R b$ and $\mathrm{G} 1 / \mathrm{S}$ phase cell cycle transition [4]. Loss of p16 could lead to unrestrained cell proliferation and genomic instability, because insensitivity to antigrowth signals is one of the hallmarks of cancer [5]. p16 has been found to lie within the 9p21 region and loss of $p 16$ is frequently observed in many malignant disorders, although overexpression of $\mathrm{p} 16$ is demonstrated in some tumors [6, 7, 8, 9].

p16 loss occurs predominantly by gene deletion, promoter methylation, and point mutation $[10,11$, 12, 13]. Allelic losses of $9 p 21$ are detected in EAC 
carcinogenesis and conflicting data exist whether these changes develop early or late in the malignant progression from Barrett's esophagus to esophageal adenocarcinoma $[14,15]$. Study of the expression of p16 could help in the comprehension of EAC pathogenesis. This marker could also become an appropriate molecule in the targeted therapy of EAC. Promising results are obtained from p16 gene therapy studies in different cancers, including esophageal cancer [16, 17, 18, 19].

Therefore, the aim of this study was to evaluate the expression of $\mathrm{p} 16$ at protein and gene level. We retrospectively assessed $\mathrm{p} 16$ protein expression by immunohistochemistry (IHC) and 9p21 (p16 gene) genomic loss by fluorescence in situ hybridization (FISH) in tissue samples of patients with EAC. Our results showed that absent expression of $p 16$ both at protein and gene level is common in EAC. Significant correlation was found also between the $\mathrm{p} 16$ protein expression and $\mathrm{p} 16$ allelic loss.

\section{MATERIAL AND METHODS}

\section{Patients and tissue sampling}

Formalin-fixed, paraffin embedded (FFPE) archival blocks from 13 patients with EAC obtained by endoscopic biopsies and surgical resections were studied. Tissue samples were evaluated by two experienced histopathologists. Medical records of all patients were thoroughly reviewed. None of the patients has been treated with neoadjuvant chemotherapy or chemoradiotherapy.

\section{Immunohistochemistry}

Immunohistochemical analysis for the protein expression of p16 was completed on all cases. $5 \mu \mathrm{m}$ thick FFPE tissue sections were placed on silanized slides, deparaffined and rehydrated in decreasing concentrations of ethanol. Antigen retrieval was carried out by immersing the slides in $10 \mathrm{mM}$ modified citrate buffer with $\mathrm{pH} 6.1$ (DAKOCytomation, Denmark) and heated in a microwave oven $(700 \mathrm{~W}) 4$ times for $5 \mathrm{~min}$. Endogenous peroxidase activity was blocked by incubation of the slides in 3\% hydrogen peroxide $\left(\mathrm{H}_{2} \mathrm{O} 2\right)$ for $5 \mathrm{~min}$. Slides were incubated for one hour at room temperature with monoclonal mouse anti-human antibody against $p 16$ (Clone 175-405, IgG1; Pharmingen, Hamburg, Germany) at a dilution of 1:50. LSAB+ visualization kit was used (DAKOCytomation, Denmark). Specimens were incubated with a secondary biotinylated anti-mouse antibody (DAKOCytomation, Denmark) for $15 \mathrm{~min}$ and then incubated with peroxidaselabelled streptavidin. The reaction was developed by immersing slides in 3,3'-diaminobenzidine (DAB) chromogen solution that results in brown staining in the positive cells. Specimens were counterstained with hematoxylin, dehydrated in ascending concentrations of ethanol and mounted with non-aqueous mounting medium. Negative controls were performed by omission of the primary antibody. Positive staining of normal, non-neoplastic epithelial cells, fibroblasts and lymphocytes within analyzed specimens served as an internal positive control. More than 500 cancer cells were counted in five representative high-power magnification fields (400x) for each specimen. Scoring was based on the percentage of the stained epithelial cancer cells and nuclear staining was considered positive. The analyzed specimens were scored into four groups as follows: 0 (negative expression, $0-25 \%$ ); $1+$ (weak expression, 26-50\%); 2+ (moderate expression, 51-75\%); and 3+ (strong expression, 76-100\%), regardless of staining intensity.

\section{FISH}

For detection of $9 p 21$ deletions, FISH was performed on the same 13 EAC specimens. Specimens were dewaxed by three 5-min immersions in xylene, dehydrated in two 5-min $100 \%$ ethanol washes, followed by drying on a $40^{\circ} \mathrm{C}$ slide warmer for $5 \mathrm{~min}$. Pretreatment kit (Vysis, Downers Grove, IL, USA) UK) was used and the slides were consecutively immersed in $0.2 \mathrm{~N}$ $\mathrm{HCL}$ for $20 \mathrm{~min}$, in purified water, and in Pretreatment Solution at $80^{\circ} \mathrm{C}$ for 15 minutes, followed by immersion of the slides twice in purified water for 1 minute, and in Wash Buffer for 5 minutes. Protease treating of the slides was done by immersing the slides in protease solution for $30 \mathrm{~min}$ at $37^{\circ} \mathrm{C}$, followed by immersion of the slides in Wash Buffer. The slides were dehydrated with increasing concentration of ethanol at room temperature. Locus specific identifier (LSI) p16 SpectrumOrange/centromeric enumeration probe (CEP) 9 Green Dual Color Probe (Vysis, Downers Grove, IL, USA) was used in the hybridization. The DNA probe (1 $\mu \mathrm{l}$ DNA probe $+7 \mu \mathrm{l}$ hybridization buffer $+2 \mu \mathrm{l}$ purified water) and the target DNA were codenatured in slide warmer at $75^{\circ} \mathrm{C}$ for $5 \mathrm{~min}$. Then the slides were coverslipped and incubated in a humidified chamber at $37^{\circ} \mathrm{C}$ for 24 hours. After washing the slides with Wash Buffer - 2XSSC/0.1\% (Vysis, Downers Grove, IL, USA) and nonionic detergent $0.3 \%$ NP40 (Vysis, Downers Grove, IL, USA), the slides were washed twice with purified water and dried at room temperature. Counterstaining was performed with $10 \mu \mathrm{l}$ 4',6-Diamidino-2-phenylindole (DAPI) (Vysis, Downers Grove, IL, USA) and slides were coverslipped. An Olympus BX60 epifluorescence microscope was utilized for scoring the signals. The loss of p16 FISH signals was analyzed in minimum 50 nonsquamous cells in every slide and damaged or overlapping nuclei were excluded from the analysis. Loss of LSI p16 probe signals compared 
to the corresponding CEP 9 or gain (> 2 FISH signals) of CEP was determined as an abnormal FISH result. We used squamous esophageal tissues as controls to establish the background hybridization variation. The cut-off levels for p16 deletions were defined as the mean percentage of cells +3 SD of the signal losses displayed in the evaluated control samples. The mean +3 SD percentage of nuclei with losses of one LSI p16 (9p21) signal (hemizygous deletion), two LSI p16 (9p21) signals (homozygous deletion) and one and two LSI p16 (9p21) signals (combination of hemizygous and homozygous deletion) was $8 \%, 5 \%$ and $6 \%$, respectively.

\section{Statistical Analysis}

Fisher's Exact Test and Cramer's V coefficient (V) were used for statistical analysis. SPSS (version
13.0; SPSS, Chicago, IL) statistical software was used for statistical analysis. Statistical significance was defined as $p<0.05$.

\section{RESULTS}

Of the patients, 10 were male and 3 were female with an age range of $45-80$ (mean of 62 years). Of the tumors, 2 were categorized as Stage 2B, 6 as Stage 3, and 5 as Stage 4 according to the TNM staging system and classification of the American Joint Committee on Cancer (AJCC). Tumor differentiation grade was determined using the criteria of the World Health Organization, and 1 tumor was graded as well differentiated (G1), 6 as moderately differentiated (G2), and 6 as poorly differentiated (G3). a

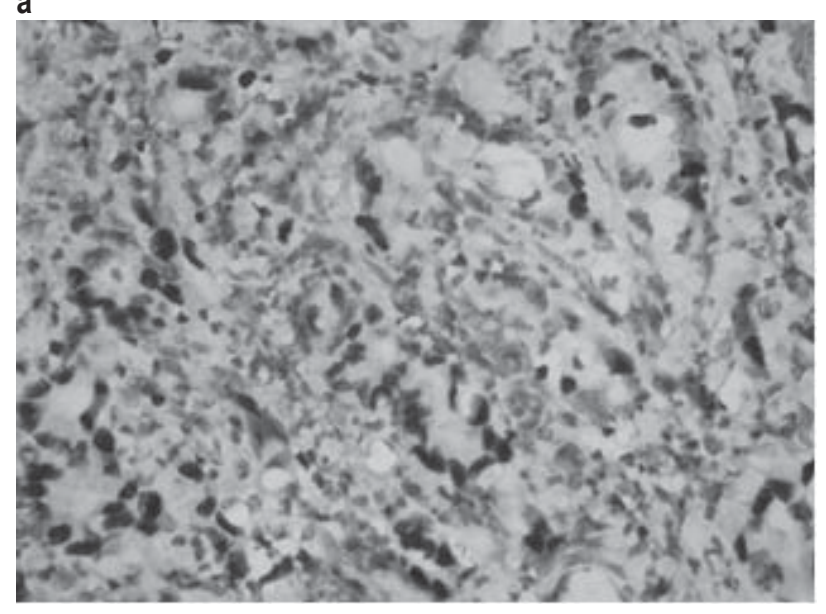

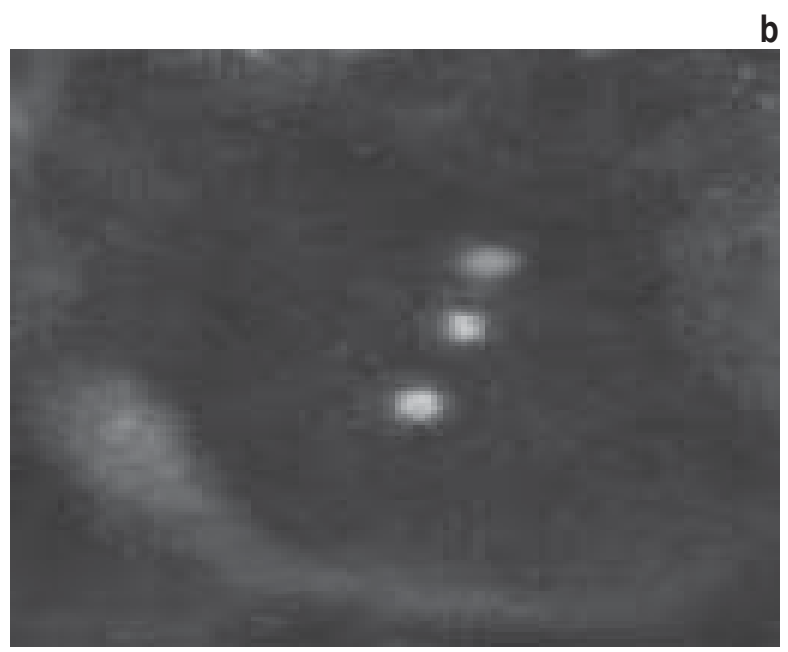

Fig. 1. Images of esophageal adenocarcinoma evaluated by fluorescence in situ hybridization and immunohistochemistry. a. Immunostaining for p16 showing strong nuclear and weaker cytoplasmic staining (400x). b. Hemizygous deletion of p16

Table 1. Summary of p16 protein and gene expression patterns in esophageal adenocarcinoma specimens analyzed by immunohistochemistry and fluorescence in situ hybridization

\begin{tabular}{|c|c|c|c|}
\hline Specimen № & p16 protein expression & p16 gene expression & \% p16 gene deletion \\
\hline 1 & Negative (-) & Negative (-) & \\
\hline 2 & Negative (-) & Positive (+) & 27 \\
\hline 3 & Negative (-) & Negative (-) & 80 \\
\hline 4 & Positive (+) & Positive (+) & 28 \\
\hline 5 & Negative (-) & Negative (-) & 38 \\
\hline 6 & Negative (-) & Positive (+) & 50 \\
\hline 7 & Positive (+ ++) & Negative (-) & 63 \\
\hline 8 & Negative (-) & Negative (-) & \\
\hline 9 & Negative (-) & Negative (-) & \\
\hline 10 & Negative (-) & Negative (-) & 48 \\
\hline 11 & Negative (-) & Positive (+) & \\
\hline 12 & Positive (+) & Negative (-) & \\
\hline 13 & Negative (-) & & \\
\hline
\end{tabular}


Loss of $\mathrm{p} 16$ protein expression was observed in 10 of $13(77 \%)$ immunohistochemically analyzed EAC specimens. Weak p16 immunostaining was found in 2 of $13(15 \%)$ EAC specimens and strong p16 immunostaining was found in 1 of $13(8 \%)$ EAC specimens (Fig. 1a). Loss of p16 gene was detected in 9 of $13(69 \%)$ EAC specimens studied by FISH. Hemizygous deletion occurred with highest frequency and was found in 7 of 13 (54\%) EAC specimens (Fig. 1b), whereas homozygous deletion of p16 and combination of hemizygous and homozygous p16 deletion were presented in 2 of $13(15 \%)$ EAC specimens. Detailed data for the protein and gene expression patterns of p16 are shown in Table 1.

Using a Fisher's Exact Test, a significant correlation was found between the loss of p16 protein expression and the $p 16$ allelic loss $(p=0.014)$ in the analyzed specimens. The statistical analysis also shows that Cramer's $V$ Coefficient $(\mathrm{V})$ is statistically significant (Approx.Sig $=0,003$ ) with $V=0,822$.

\section{DISCUSSION}

EAC occurs commonly with increasing age, which coincides with our findings. Higher number of men with EAC in our study is anticipated, because for unknown reasons male predominance is particularly strong in this cancer [20,21]. More severe gastroesophageal reflux found in men is considered as putative contributing factor for higher incidence of EAC in male individuals [22].

FISH and IHC are proper and complimentary techniques to estimate the molecular alterations at protein and gene level in human cancers. $\mathrm{ICH}$ detects protein (antigen) expression within tissues by application of antibodies and is very helpful in the diagnosis of different cancers [23, 24]. Advantages of $\mathrm{IHC}$ are high sensitivity and comparatively low cost. FISH technique is also an important tool in cancer research and is characterized by the utilization of fluorescent DNA probes to localize and visualize gene or chromosome abnormalities [25]. FISH is possible due to the stability of the DNA double helix and the ability of the DNA helix to renature. FISH is more accurate, reproducible and notably could be used for examination of resting cells in interphase. FISH allows analysis of chromosomal disturbances even in samples in bad condition. Drawbacks of FISH include higher price, inability to value the pathomorphological alterations and the long time to count FISH signals by fluorescence microscopy [26, 27].

We found significant aberrant protein expression of tumor suppressor p16 in EAC tissue samples. In concert with our findings, Langer et al. identified a loss of $\mathrm{p} 16$ expression in $76 \%$ of immunohistochemically stained EAC samples [28]. Hardie et al. also found sizable loss of protein expression of $\mathrm{p} 16$ in $85 \%$ of the explored by IHC esophageal adenocarcinomas [29]. The expression of $p 16$ in $23 \%$ of the specimens in our study supports the idea that $p 16$ is not always implicated in the development of EAC and most likely other genetic disturbances could drive the uncontrolled cell proliferation and neoplastic progression. The pronounced lack of immunohistochemical expression of $\mathrm{p} 16$ protein in this study presumes that the cell cycle control is impaired in the examined EAC tissue samples.

Endoscopic brushing cytology specimens are normally used for FISH analysis of molecular changes in EAC, but FFPE tissue is also an attractive and proven option [30]. Moreover, use of FFPE tissue allows retrospective sample analysis [31]. Exploration of $p 16$ (9p21) by FISH is successfully utilized for EAC detection [32]. We found prominent loss of $p 16$ gene by means of FISH. In agreement with our findings, although reporting higher rate of p16 locus loss, are data presented in other studies. Fahmy et al., using cytological specimens, found noticeable loss of the 9p21 signals in $9(90 \%)$ of analyzed by FISH samples with EAC [33]. Similarly, Doak et al. reported a hemizygous deletion of $p 16$ (9p21) in 7 (100\%) patients with EAC in their study for determination of genetic alterations in EAC pathogenesis by FSIH [34]. In contrast to other studies, we did not observe a gain of chromosome 9 in samples with EAC. Fahmy et al. discovered a net gain of chromosome 9 in all EAC cases with p16 loss [33]. In the investigation performed by Brankley et al., $80 \%$ of the polysomic EAC cells showed hemizygous, homozygous, or relative loss of 9p21, whereas loss of 9p21 without associated chromosomal gain in EAC cells was not seen [35]. It is possible that molecular carcinogenesis of EAC is following distinct pathways in the cases when the loss of $p 16$ occurs simultaneously with a gain of chromosome 9. Nevertheless, the abrogation of the normal p16 function could promote high cell proliferation rate in the esophageal tissue and enhance the development of EAC.

The estimated significant correlation between the p16 protein expression and FISH signals in the current study could be due to the fact that $\mathrm{p} 16$ inactivation in EAC is often accomplished by allelic loss [14]. We must mention, however, that one of the analyzed specimens manifested positive p16 gene and negative $\mathrm{p} 16$ protein expression. Alternative mechanisms like $\mathrm{p} 16$ promoter methylation or $\mathrm{p} 16$ gene mutation could be the reasons for loss of $p 16$ protein expression in this case. Methylation of $\mathrm{p} 16$ promoter 
is considered as common mechanism of p16 gene derailment during molecular pathogenesis of EAC, whereas $\mathrm{p} 16$ gene mutation is less probable $[15,36$, $37,38,39]$. It is plausible also that very small deletion of $p 16$ could occur, which does not delete the entire LSI p16 probe target and consequently cannot be detected by FISH technique.

Limitation of this study is the relatively small number of analyzed patients. In patients with EAC, simultaneous exploration of gene and protein expression of other biomarkers (cyclin-D-cdk4/6 complex, retinoblastoma protein, E2F transcription factor and p53) interfering in the $\mathrm{p} 16$ signaling pathway could contribute to a better understanding of EAC.

\section{CONCLUSION}

Our data suggest that the absence of p16 protein expression and allelic loss of p16 gene are common molecular disturbances in EAC. Significant association between protein and gene expression supposes that $\mathrm{p} 16$ (9p21) deletion account for appreciable part of the p16 protein loss in EAC. IHC and FISH are reliable methods for detection of p16 changes at protein and chromosomal level in EAC, but larger studies are needed to reveal the exact role of $p 16$ in the carcinogenesis of EAC.

\section{REFERENCES}

1. Hur C, Miller M, Kong CY, et al. Trends in esophageal adenocarcinoma incidence and mortality. Cancer. 2013;119:1149-1158.

2. Thrift AP, Whiteman DC. The incidence of esophageal adenocarcinoma continues to rise: analysis of period and birth cohort effects on recent trends. Ann Oncol. 2012;23:3155-3162.

3. Clemons NJ, Phillips WA, Lord RV. Signaling pathways in the molecular pathogenesis of adenocarcinomas of the esophagus and gastroesophageal junction. Cancer Biol Ther. 2013;14:782-795.

4. Serrano M, Hannon GJ, Beach D. A new regulatory motif in cell-cycle control causing specific inhibition of cyclin D/CDK4. Nature. 1993;366:704-707.

5. Hanahan D, Weinberg RA. The hallmarks of cancer. Cell. 2000;100:57-70.

6. Kamb A, Gruis NA, Weaver-Feldhaus J, et al. A cell cycle regulator potentially involved in genesis of many tumor types. Science. 1994;264:436-440.

7. Serrano M, Lee H, Chin L, Cordon-Cardo C, Beach D, DePinho RA. Role of the INK4a locus in tumor suppression and cell mortality. Cell. 1996;85:27-37.

8. Liggett WH Jr, Sidransky D. Role of the p16 tumor suppressor gene in cancer. J Clin Oncol. 1998;16:1197-1206.

9. Romagosa C, Simonetti S, López-Vicente L, et al. p16(Ink4a) overexpression in cancer: a tumor suppressor gene associated with senescence and high-grade tumors. Oncogene. 2011;30:2087-2097.

10. Nobori T, Miura K, Wu D, Lois A, Takabayashi K, Carson DA. Deletions of the cyclin- dependent kinase-4 inhibitor gene in multiple human cancers. Nature. 1994;368:753-756.
11. Liu $Q$, Yan $Y X$, McClure $M$, Nakagawa $H$, Fujimura F, Rustgi AK. MTS-1 (CDKN2) tumor suppressor gene deletions are a frequent event in esophagus squamous cancer and pancreatic adenocarcinoma cell lines. Oncogene. 1995;10:619-622.

12. Kamb A, Gruis NA, Weaver-Feldhaus J, et al. A cell cycle regulator potentially involved in genesis of many tumor types. Science. 1994;264:436-440.

13. Cairns P, Polascik TJ, Eby $\mathrm{Y}$, et al. Frequency of homozygous deletion at $p 16 / C D K N 2$ in primary human tumours. Nat Genet. 1995;11:210-212.

14. Barrett MT, Sanchez CA, Galipeau PC, Neshat K, Emond M, Reid BJ. Allelic loss of 9p21 and mutation of the CDKN2/p16 gene develop as early lesions during neoplastic progression in Barrett's esophagus. Oncogene. 1996;13:1867-1873.

15. González MV, Artímez ML, Rodrigo L, et al. Mutation analysis of the p53, APC, and p16 genes in the Barrett's oesophagus, dysplasia, and adenocarcinoma. J Clin Pathol. 1997;50:212-217.

16. Lu Y, Zhang X, Zhang J. Inhibition of breast tumor cell growth by ectopic expression of $\mathrm{p} 16 / \mathrm{INK} 4 \mathrm{~A}$ via combined effects of cell cycle arrest, senescence and apoptotic induction, and angiogenesis inhibition. J Cancer. 2012;3:333-344.

17. $\mathrm{Hu} \mathrm{H}, \mathrm{Li} \mathrm{Z}$, Chen J, et al. P16 reactivation induces anoikis and exhibits antitumour potency by downregulating Akt/ survivin signalling in hepatocellular carcinoma cells. Gut. 2011;60:710-721.

18. Allay JA, Steiner MS, Zhang Y, Reed CP, Cockroft J, Lu Y. Adenovirus p16 gene therapy for prostate cancer. World J Urol. 2000;18:111-120.

19. Schrump DS, Chen GA, Consuli U, Jin X, Roth JA. Inhibition of esophageal cancer proliferation by adenovirally mediated delivery of p16INK4. Cancer Gene Ther. 1996;3:357-364.

20. Xie SH, Lagergren J. A global assessment of the male predominance in esophageal adenocarcinoma. Oncotarget. 2016;7:38876-38883.

21. Bollschweiler E, Wolfgarten E, Gutschow C, Hölscher AH. Demographic variations in the rising incidence of esophageal adenocarcinoma in white males. Cancer. 2001;92:549-555.

22. Lagergren J, Lagergren P. Recent developments in esophageal adenocarcinoma. CA Cancer J Clin. 2013;63:232-248.

23. Duraiyan J, Govindarajan R, Kaliyappan K, Palanisamy M. Applications of immunohistochemistry. J Pharm Bioallied Sci. 2012;4(Suppl 2):S307-9.

24. Le Beau MM. Fluorescence in situ hybridization in cancer diagnosis. Important Adv Oncol. 1993;29-45.

25. Hu L, Ru K, Zhang L, et al. Fluorescence in situ hybridization (FISH): an increasingly demanded tool for biomarker research and personalized medicine. Biomark Res. 2014;2:3.

26. Trask BJ. Fluorescence in situ hybridization: applications in cytogenetics and gene mapping. Trends Genet. 1991;7:149-154.

27. Waters JJ, Barlow AL, Gould CP. Demystified ... FISH. Mol Pathol. 1998;51:62-70.

28. Langer R, Von Rahden $\mathrm{BH}$, Nahrig J, et al. Prognostic significance of expression patterns of c-erbB-2, p53, p16INK4A, p27KIP1, cyclin D1 and epidermal growth factor receptor in oesophageal adenocarcinoma: a tissue microarray study. J Clin Pathol. 2006;59:631-634.

29. Hardie LJ, Darnton SJ, Wallis YL, et al. p16 expression in Barrett's esophagus and esophageal adenocarcinoma: association with genetic and epigenetic alterations. Cancer Lett. 2005;217:221-230.

30. Doak SH, Jenkins GJS, Parry EM, et al. Characterisation of p53 status at the gene, chromosomal and protein levels in oesophageal adenocarcinoma. Br J Cancer. 2003;89:1729-1735. 
31. Zordan A. Fluorescence in situ hybridization on formalinfixed, paraffin-embedded tissue sections. Methods Mol Biol. 2011;730:189-202.

32. Brankley SM, Wang KK, Harwood AR, et al. The development of a fluorescence in situ hybridization assay for the detection of dysplasia and adenocarcinoma in Barrett's esophagus. J Mol Diagn. 2006;8:260-267.

33. Fahmy M, Skacel M, Gramlich TL, et al. Chromosomal gains and genomic loss of p53 and p16 genes in Barrett's esophagus detected by fluorescence in situ hybridization of cytology specimens. Mod Pathol. 2004;17:588-596.

34. Doak SH, Jenkins GJ, Parry EM, et al. Chromosome 4 hyperploidy represents an early genetic aberration in premalignant Barrett's oesophagus. Gut. 2003;52:623-628.

35. Brankley SM, Fritcher EG, Smyrk TC, et al. Fluorescence in situ hybridization mapping of esophagectomy specimens from patients with Barrett's esophagus with high-grade dysplasia or adenocarcinoma. Hum Pathol. 2012;43:172-179.

36. Maley CC, Galipeau PC, Li X, Sanchez CA, Paulson TG, Reid BJ. Selectively advantageous mutations and hitchhikers in neoplasms: p16 lesions are selected in Barrett's esophagus. Cancer Res. 2004;64:3414-3127.

37. Wang JS, Guo M, Montgomery E, et al. DNA promoter hypermethylation of p16 and APC predicts neoplastic progression in Barrett's esophagus. Am J Gastroenterol. 2009;104:2153-2160.

38. Klump B, Hsieh CJ, Holzmann K, Gregor M, Porschen R. Hypermethylation of the CDKN2/p16 promoter during neoplastic progression in Barrett's esophagus. Gastroenterology. 1998;115:1381-1386.

39. Wong DJ, Barrett MT, Stöger R, Emond MJ, Reid BJ. p16INK4a promoter is hypermethylated at a high frequency in esophageal adenocarcinomas. Cancer Res. 1997;57:2619-2622. 